\title{
IL4-10 Fusion Protein Is a Novel Drug to Treat Persistent Inflammatory Pain
}

\author{
@Niels Eijkelkamp, ${ }^{1,2}$ Cristine Steen-Louws, ${ }^{1}$ Sarita A. Y. Hartgring, ${ }^{1}$ Hanneke L. D. M. Willemen, ${ }^{2}$ Judith Prado, ${ }^{1}$ \\ Floris P. J. G. Lafeber, ${ }^{3}{ }^{\circledR}$ Cobi J. Heijnen, ${ }^{4}$ C. E. Hack, ${ }^{1}$ Joel A. G. van Roon, ${ }^{1 \star}$ and Annemieke Kavelaars ${ }^{4 \star}$ \\ Laboratories of ${ }^{1}$ Translational Immunology and ${ }^{2}$ Neuroimmunology and Developmental Origins of Disease and ${ }^{3}$ Department of Rheumatology and Clinical \\ Immunology, University Medical Center Utrecht, 3584 EA Utrecht, The Netherlands, and ${ }^{4}$ Neuroimmunology Laboratory, Department of Symptom \\ Research, MD Anderson Cancer Center, University of Texas, Houston, Texas 77030
}

Chronic pain is a major clinical problem that is difficult to treat and requires novel therapies. Although most pain therapies primarily target neurons, neuroinflammatory processes characterized by spinal cord and dorsal root ganglion production of proinflammatory cytokines play an important role in persistent pain states and represent potential therapeutic targets. Anti-inflammatory cytokines are attractive candidates to regulate aberrant neuroinflammatory processes, but the therapeutic potential of these cytokines as stand-alone drugs is limited. Their optimal function requires concerted actions with other regulatory cytokines, and their relatively small size causes rapid clearance. To overcome these limitations, we developed a fusion protein of the anti-inflammatory cytokines interleukin 4 (IL4) and IL10. The IL4-10 fusion protein is a $70 \mathrm{kDa}$ glycosylated dimeric protein that retains the functional activity of both cytokine moieties. Intrathecal administration of IL4-10 dose-dependently inhibited persistent inflammatory pain in mice: three IL4-10 injections induced full resolution of inflammatory pain in two different mouse models of persistent inflammatory pain. Both cytokine moieties were required for optimal effects. The IL4-10 fusion protein was more effective than the individual cytokines or IL4 plus IL10 combination therapy and also inhibited allodynia in a mouse model of neuropathic pain. Mechanistically, IL4-10 inhibited the activity of glial cells and reduced spinal cord and dorsal root ganglion cytokine levels without affecting paw inflammation. In conclusion, we developed a novel fusion protein with improved efficacy to treat pain, compared with wild-type anti-inflammatory cytokines. The IL4-10 fusion protein has potential as a treatment for persistent inflammatory pain.

Key words: anti-inflammatory cytokines; fusion protein; glia; inflammatory pain

\section{Significance Statement}

The treatment of chronic pain is a major clinical and societal challenge. Current therapies to treat persistent pain states are limited and often cause major side effects. Therefore, novel analgesic treatments are urgently needed. In search of a novel drug to treat chronic pain, we developed a fusion protein consisting of two prototypic regulatory cytokines, interleukin 4 (IL4) and IL10. The work presented in this manuscript shows that this IL4-10 fusion protein overcomes some major therapeutic limitations of pain treatment with individual cytokines. The IL4-10 fusion protein induces full resolution of persistent inflammatory pain in two different mouse models. These novel findings are significant, as they highlight the IL4-10 fusion protein as a long-needed potential new drug to stop persistent pain states.

\section{Introduction}

Chronic pain is a major clinical problem affecting $>20 \%$ of the world population, resulting in severe reduction in the quality of

Received Jan. 6, 2016; revised April 28, 2016; accepted May 18, 2016

Author contributions: N.E., C.J.H., C.E.H., J.A.G.v.R., and A.K. designed research; N.E., C.S.-L., S.A.Y.H., H.L.D.M.W., and J.P. performed research;F.P.J.G.L. and C.E.H. contributed unpublished reagents/analytic tools; N.E., C.S.-L., S.A.Y.H., H.L.D.M.W., and J.P. analyzed data; N.E., F.P.J.G.L., C.J.H., C.E.H., J.A.G.v.R., and A.K. wrote the paper.

This work was supported in parts by a Utrecht University Life Science Seed Grant and U.S. National Institutes of Health Grants R01 NS073939 and R01 NS074999. The content is solely the responsibility of the authors and does not necessarily represent the official views of the National Institutes of Health. We thank Mirjam Maas and Sabine Versteeg for their technical assistance. life [Breivik et al., 2006; Institute of Medicine (US) Committee on Advancing Pain Research, 2011]. Chronic pain is a major complaint of many patients suffering from chronic inflammatory diseases, including rheumatoid arthritis and inflammatory bowel disease. In these conditions, pain may even persist after successful

\footnotetext{
*J.A.G.v.R. and A.K. contributed equally to this work.

The authors declare no competing financial interests.

Correspondence should be addressed to Niels Eijkelkamp, Laboratory of Translational Immunology, University Medical Center Utrecht, Lundlaan 6, Room KC03.068.0, 3584 EA Utrecht, The Netherlands. E-mail: n.eijkelkamp@umcutrecht.nl.

DOI:10.1523/JNEUROSCI.0092-16.2016

Copyright $\odot 2016$ the authors $\quad 0270-6474 / 16 / 367353-11 \$ 15.00 / 0$
} 
treatment of the inflammation (Bielefeldt et al., 2009; Lee et al., 2011; Lomholt et al., 2013). Current treatments provide modest pain relief at best, due to lack of effectiveness or because treatment has to be suspended due to severe side effects (Borsook et al., 2014). Therefore, development of novel therapies is required.

Most chronic pain therapies primarily target neurons or peripheral inflammation. However, persistent inflammatory pain is the result of neuronal plasticity characterized by peripheral sensitization of primary sensory neurons and central sensitization in the spinal dorsal horn that involves local neuroimmune interactions. Persistent pain states have been associated with activation of glial cells in the spinal cord and dorsal root ganglia (DRGs) in rodent models for chronic pain (Graeber and Christie, 2012; Ji et al., 2013). Human data support a role for glial cells in different chronic pain states (Brisby et al., 1999; Banati et al., 2001; Del Valle et al., 2009; Shi et al., 2012; Loggia et al., 2015). Activated glial cells in the dorsal horn of the spinal cord and infiltrating macrophages or activated satellite glial cells in the DRGs produce proinflammatory cytokines that sensitize the sensory system (Ren and Dubner, 2010). Therefore, these neuroinflammatory pathways, including spinal cord and DRG cytokine production and glial cell activation, represent potential therapeutic targets for treating persistent pain states (Ren and Dubner, 2010; Graeber and Christie, 2012; Ji et al., 2013, 2014).

Anti-inflammatory cytokines are attractive candidates to dampen spinal cord and DRG cytokine production and glial activation (Milligan et al., 2005). The mechanism of action of regulatory anti-inflammatory cytokines, such as interleukin 4 (IL4) and IL10, differs significantly from that of biologics that inhibit single (pro)inflammatory mediators [e.g., anti-tumor necrosis factor (TNF) therapy]. These regulatory cytokines downregulate inflammatory responses by turning off release and production of multiple mediators, including cytokines, chemokines, proteases, and reactive oxygen species. In addition, anti-inflammatory cytokines shift cells toward an inhibitory/regulatory profile. Importantly, glial cells and sensory neurons respond to antiinflammatory cytokines. The regulatory cytokines IL4 and IL10 inhibit glial cell proliferation (Kloss et al., 1997). IL4 skews microglia toward an M2a regulatory phenotype (Pepe et al., 2014), and IL10 administration reduces astrocyte activation (Balasingam and Yong, 1996) and strongly reduces lipopolysaccharide (LPS)-induced cytokine production by microglia (Balasingam and Yong, 1996; Lodge and Sriram, 1996; Sawada et al., 1999).

Strong evidence exists for a therapeutic potential of IL10 to inhibit pain, whereas a limited number of studies have shown a therapeutic potential for IL4 (Cunha et al., 1999; Vale et al., 2003; Hao et al., 2006; Kwilasz et al., 2015). Nonetheless, the therapeutic potential of the native unmodified anti-inflammatory cytokines as stand-alone drugs is limited. First, the optimal function of these cytokines requires them to act in concert with other immunoregulatory cytokines (van Roon et al., 1996, 2001; Joosten et al., 1997). Second, their relatively small size causes rapid clearance, thereby reducing their bioavailability.

To overcome these limitations, we designed a novel strategy to fuse regulatory cytokines into one molecule to promote efficacy in treating pain by facilitating synergy and bioavailability. We developed a fusion protein of IL4 and IL10 that combines the anti-inflammatory actions of the two regulatory cytokines into one molecule. We demonstrate that the functional activity of both cytokine moieties was maintained in IL4-10 and that it reversed persistent inflammatory pain in mouse models through the regulation of neuroinflammatory responses in the spinal cord and DRG.

\section{Materials and Methods}

Construction, production, and purification of IL4-10 fusion protein. The IL4-10 fusion protein was produced by transient transfection of HEK293 cells (tested negative for mycoplasma contamination) with a pUPEexpression vector containing a cystatin signal sequence and synthetic cDNA coding for the peptide sequence (U-Protein Express; Durocher et al., 2002). Glycan capping with sialic acid residues was optimized by cotransfection with a vector carrying the $\beta$-galactoside- $\alpha 2,3$ sialyltransferase 5 (SIAT9, Homo sapiens) transgene. Cells were cultured in FreeStyle medium (Invitrogen) with $0.9 \%$ primatone and $\sim 0.04 \%$ fetal calf serum, total volume $1 \mathrm{~L}$, for $5 \mathrm{~d}$. Supernatant was collected, concentrated 10-fold (10 kDa QuixStand hollow fiber cartridge; GE Healthcare), and diafiltrated against PBS, pH 7.4. Precipitates were removed by passing over a glass syringe filter. Supernatant was stored in aliquots at $-80^{\circ} \mathrm{C}$.

Ion exchange chromatography. IL4-10 fusion protein was purified using cation exchange chromatography (HiTrap SP FF $1 \mathrm{ml}$ column; GE Healthcare) on an AKTAprime Plus (GE Healthcare). Low-salt buffer (buffer A) consisted of $10 \mathrm{~mm}$ phosphate, $\mathrm{pH}$ 6.5. High-salt buffer (buffer B) consisted of buffer A with $1 \mathrm{~m} \mathrm{NaCl}$. Before injection, $50 \mathrm{ml}$ of supernatant was diluted 1:5 in buffer A. A linear gradient to $100 \%$ buffer B (in $20 \mathrm{~min}$; flow rate, $1 \mathrm{ml} / \mathrm{min}$ ) was used to elute IL4-10 fusion protein. One milliliter fractions were collected and analyzed for IL4-10 fusion protein content using IL4 and IL10 ELISA. Fractions containing IL4-10 fusion protein were pooled, diafiltrated against $\mathrm{PBS}, \mathrm{pH} 7.4$, and concentrated to yield a $\sim 20 \mu \mathrm{g} / \mathrm{ml}$ IL4-10 fusion protein batch.

Size exclusion chromatography. Molecular weight was determined by high-performance size exclusion chromatography (SEC) on a highperformance liquid chromatography system (Shimadzu). Running buffer consisted of $50 \mathrm{~mm}$ phosphate, $\mathrm{pH} 7.0$, and $0.5 \mathrm{M} \mathrm{NaCl}$ (flow rate, 0.35 $\mathrm{ml} / \mathrm{min}$; 35 bar). The column (BioSuite 125, $4 \mu \mathrm{m}$ ultra-high resolution SEC; Waters) was calibrated with reference proteins. Fifty microliters of $20 \mu \mathrm{g} / \mathrm{ml}$ (ion exchange chromatography) purified IL4-10 fusion protein was analyzed. Fractions ( $175 \mu \mathrm{l}$ ) were collected, and IL 4 and IL10 content were measured with ELISA (in 1:500 dilution). Similar runs with IL4 and IL10 (Sigma-Aldrich) were performed.

IL4-10 fusion protein detection. IL4 and IL10 content were measured with ELISA (Pelipair ELISA kits; Sanquin) according to the manufacturer's instructions. Results were compared with those for recombinant IL4 and IL10 provided by the manufacturer.

A cross-ELISA specific for the IL4-10 fusion protein was generated by modification of the IL4 and IL10 ELISA. Anti-IL4-coated plates were combined with biotinylated anti-IL10 monoclonal antibody and vice versa. Antibodies from the IL4 and IL10 Pelipair ELISA (Sanquin) were used and further performed according to manufacturer's instructions. An amount of IL4-10 fusion protein equivalent to $75 \mathrm{pg} / \mathrm{ml}$ recombinant IL10 and IL4-10 was tested. As there is no standard for this assay, results are given as optical density at $450 \mathrm{~nm}$.

SDS-PAGE and Western blotting. Samples were diluted 1:1 in sample buffer (Tris-HCl, pH 6.8, 25\% glycerol, 2\% SDS, 0.01\% bromophenol blue; Bio-Rad) containing $100 \mathrm{~mm}$ DL-dithiotreitol (Sigma-Aldrich), incubated $10 \mathrm{~min}$ at $100^{\circ} \mathrm{C}$, and loaded on a $12 \%$ polyacrylamide gel (MiniPROTEAN-TGX; Bio-Rad). Markers (WesternC Standard, 250-10 kDa; Bio-Rad) were run in a separate lane. Electrophoresis was performed at $150 \mathrm{~V}$ for $1 \mathrm{~h}$ under reducing conditions (Tris/glycine/SDS buffer; Bio$\mathrm{Rad})$. After electrophoresis, proteins were transferred $(100 \mathrm{~V}, 1 \mathrm{~h})$ to a polyvinylidene difluoride (PVDF) membrane (Bio-Rad). Thereafter, the PVDF membrane was incubated in PBS 0.1\% Tween-20 (Merck) containing $4 \%$ milk powder (Elk; Campina). The membrane was incubated with mIgG1 anti-human IL4 or mIgG1 anti-human IL10 (Santa Cruz Biotechnology), followed by horseradish peroxidase (HRP)-conjugated goat anti-mouse IgG (Santa Cruz Biotechnology) and WesternC-markerdetecting antibody (StrepTactin-HRP; Bio-Rad). Some experiments required deglycosylation of IL4-10 fusion protein before electrophoresis by PNGaseF (Sigma-Aldrich), according to manufacturer's instructions.

Animals. All animal experiments were performed in accordance with international guidelines and with prior approval from the University Medical Center Utrecht experimental animal committee. Before ethical 
a

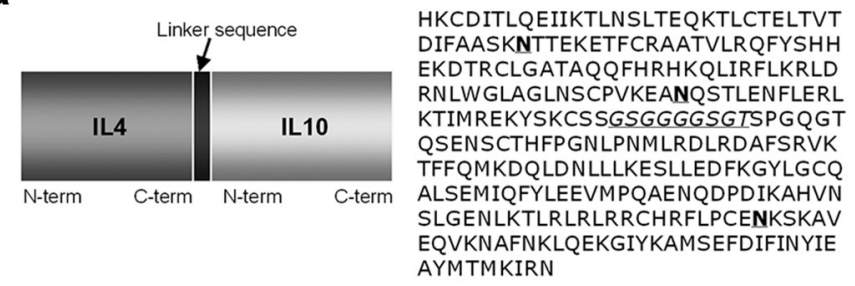

b

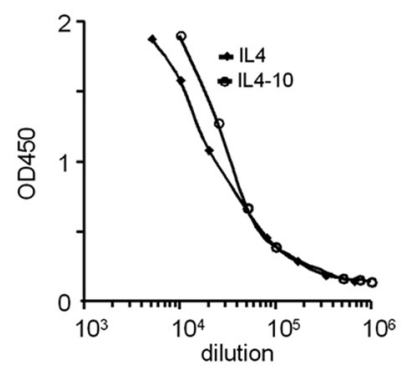

C

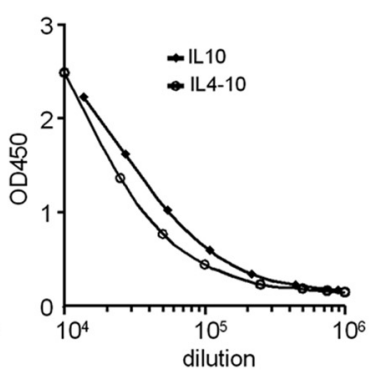

d

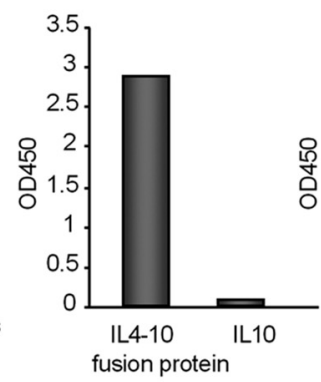

e

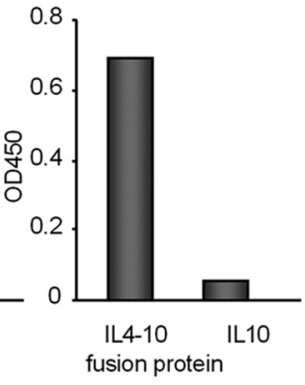

f

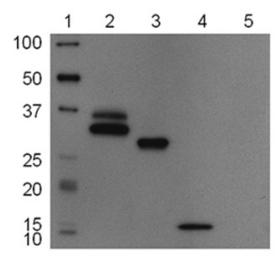

g

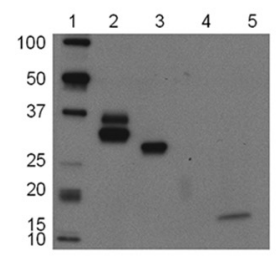

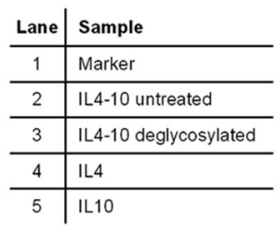

h

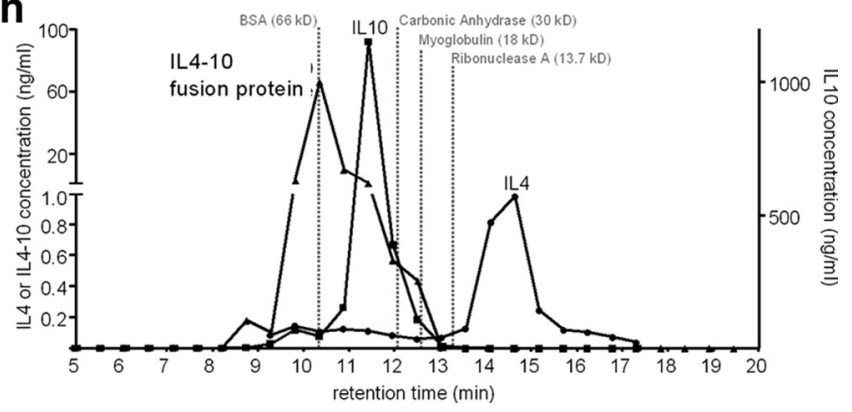

Figure 1. Molecular and functional characterization of the IL4-10 fusion protein. $\boldsymbol{a}$, Schematic overview of the IL4-10 fusion protein and its amino acid sequence. The linker sequence is indicated in italic, and potential N-linked glycosylation sites are indicated in bold. $\boldsymbol{b}$, $\boldsymbol{c}$, Supernatant of HEK293 cells expressing IL4-10 fusion protein was tested in sandwich ELISAs for IL4 (b) and IL10 (c) and compared with the wild-type cytokines. $\boldsymbol{d}, \boldsymbol{e}, \mathrm{A}$ cross-ELISA with anti-IL4 as a capture antibody and biotinylated anti-IL10 as a detecting antibody (d) and vice versa (capture, anti-IL10; detection, anti-IL $4 ; \boldsymbol{e}$ ) indicated presence of the IL4-10 fusion protein. Recombinant IL10 was used as a negative control. $\boldsymbol{f}, \boldsymbol{g}$, Western blot analysis of untreated and deglycosylated purified supernatants containing IL4-10 fusion protein was detected with $(\boldsymbol{f})$ anti-IL4 or $(\boldsymbol{g})$ anti-IL10. Untreated IL4-10 fusion protein contains both IL4 and IL10 and migrates as a double band (lane 2). Upon deglycosylation with pNGaseF, the IL4-10 fusion protein migrated as one band with a molecular weight of $34 \mathrm{kDa}$ (lane 3). $\boldsymbol{h}$, The molecular weights of IL4-10 fusion protein, IL4, and IL10 were estimated based on the retention time of standard proteins (positions by dotted gray lines) in a size-exclusion chromatography. IL 4 eluted as a monomer ( $\sim 15 \mathrm{kDa})$, whereas the molecular size of IL10 ( $\sim 36 \mathrm{kDa})$ and the IL4-10 fusion protein ( 70 kDa) were consistent with a dimer. Data are expressed as mean and SEM.

permissions approval, power calculations were performed to determine the sample size to detect a minimal predefined effect size. All animals were allocated to a group before the start of any measurements or treatment. Experiments were conducted using both male and female C57BL/6 mice aged 8-12 weeks. Observers performing behavioral experiments were blinded to treatment.

Persistent inflammatory pain and assessment of hypersensitivity. Carrageenan (2\%, $20 \mu \mathrm{l}$; Sigma-Aldrich) was injected in both hindpaws to induce persistent inflammatory pain. Twenty microliters of complete Freund's adjuvant [CFA; $1 \mathrm{mg}$ of Mycobacterium tuberculosis (H37Ra, ATCC 25177), heat killed and dried, $0.85 \mathrm{ml}$ paraffin oil, and $0.15 \mathrm{ml}$ mannide monooleate; Sigma-Aldrich] was injected in one hindpaw to induce persistent inflammatory pain, while the other paw received $20 \mu \mathrm{l}$ of vehicle (saline). Heat withdrawal latency times were determined using the Hargreaves test (IITC Life Science) as described previously (Hargreaves et al., 1988). Mechanical hypersensitivity was measured using von Frey hairs (Stoelting), and the 50\% paw-withdrawal threshold was calculated using the up-and-down method (Chaplan et al., 1994).

The IL4-10 fusion protein and recombinant human IL4 and IL10 were produced in HEK293 cells (Sigma-Aldrich) and injected intrathecally (Eijkelkamp et al., 2013). Each mouse received $5 \mu l$, and concentration was adjusted to the appropriate dosing. Receptor-blocking antibodies against mouse IL4 receptor and IL10 receptor (BD PharMingen) were administered together with the IL4-10 fusion protein at a dose of $6 \mu \mathrm{g}$ per mouse.
Paw thickness was measured using a Digimatic micrometer (Mitutoyo).

Spared nerve injury surgery was performed as described previously (Willemen et al., 2012; Zhou et al., 2015). Briefly, the sural common peroneal and tibial branches of the left sciatic nerve were exposed under isoflurane anesthesia. The tibial and common peroneal nerves were transected, while the sural nerve was kept intact. IL4-10 was injected intrathecal at days 6 and 7 after transection, and pain behaviors were measured 3 and $6 \mathrm{~h}$ after administration.

To assess motor function, mice were individually placed in a clean cage identical to the home cage but without bedding and were permitted to freely explore the whole cage for $10 \mathrm{~min}$. A new cage was used for each mouse. The cage was divided virtually into four quadrants. Locomotor activity was quantified by counting the number of quadrant entries during the last $5 \mathrm{~min}$. The number of full rears also was counted during the same time interval. Scoring was conducted by a well-trained observer who was blind to treatments.

Immunohistochemistry. Spinal cords and DRGs were excised from mice perfused with $4 \%$ paraformaldehyde in PBS. Tissues were postfixed, cryoprotected in sucrose, embedded in optimal cutting temperature compound, and frozen at $-80^{\circ} \mathrm{C}$. Frozen sections of DRGs and spinal cord (lumbar L3-L5 section) were stained with rabbit anti-Ibal (1:1000; catalog \#019-19741, Wako Pure Chemical Industries) or mouse anti-glial fibrillary acidic protein (GFAP; catalog \#bm2287, Acris) or rabbit-anti- 

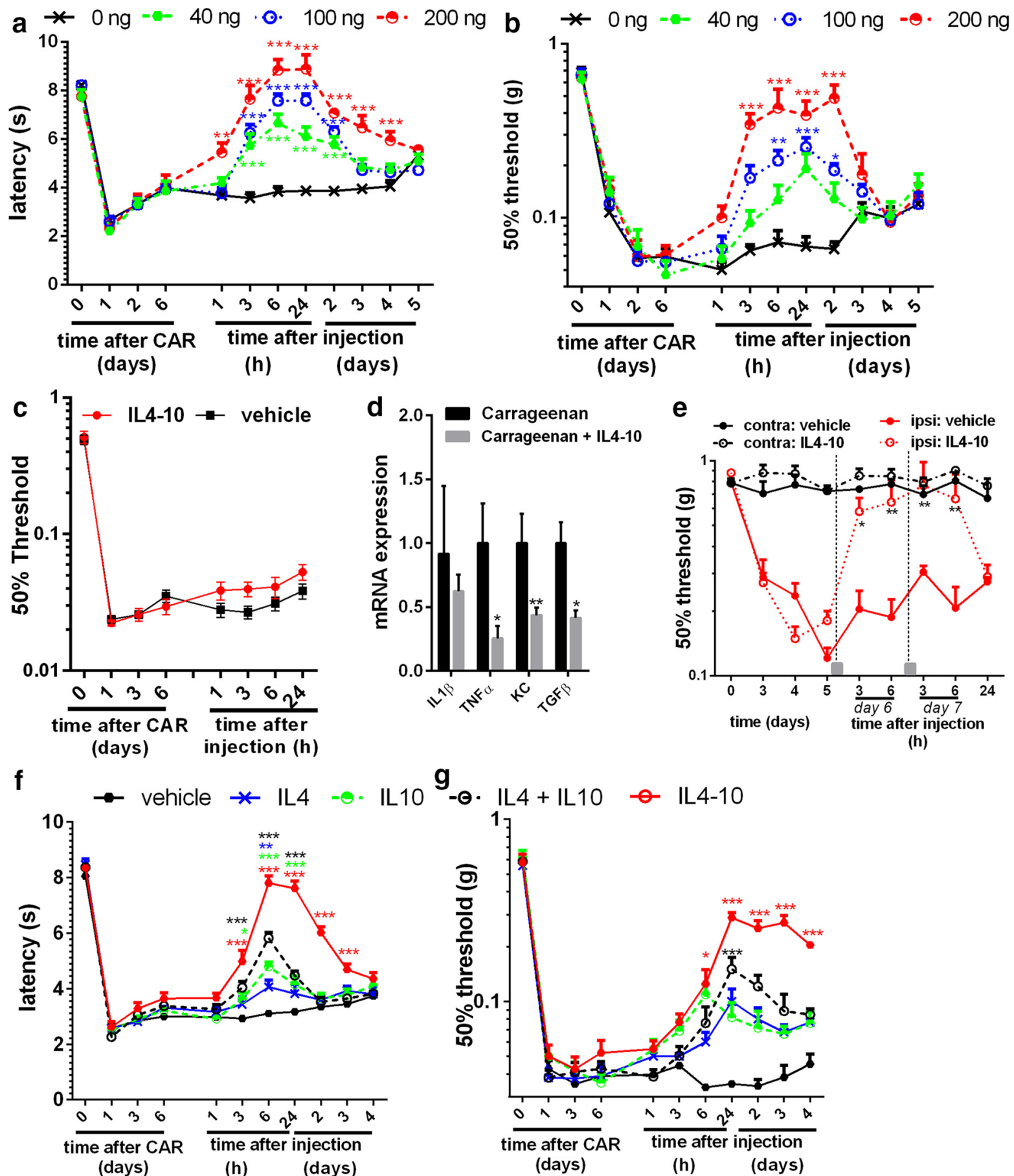

9.0. IL4 + IL10 -
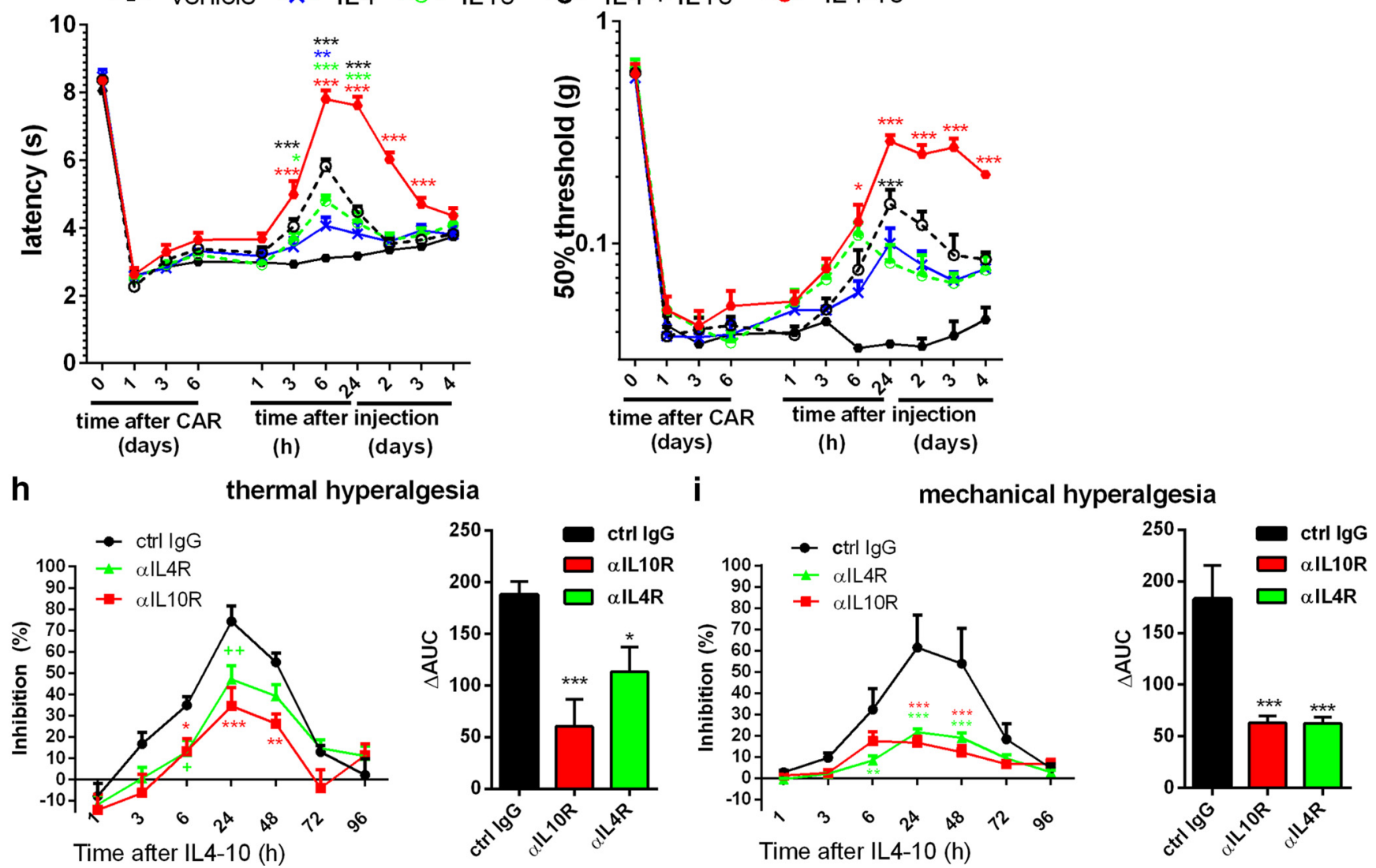
GFAP (catalog \#04-1062, Millipore) followed by Alexa Fluor 488conjugated or 594-conjugated secondary donkey antibodies (Invitrogen). Photographs were taken with a Zeiss Axio Observer microscope using identical exposure times for all slides. Iba1- and GFAP-positive areas were analyzed with the NIH ImageJ program using identical thresholds to identify area positive for staining. At least three slides per animals were analyzed in a blinded fashion.

Primary spinal microglia and astrocyte culture. Microglia were isolated from spinal cords using enzymatic digestion with papain (Worthington Biochemical) as described previously (Yip et al., 2009). Adult spinal cord astrocytes were isolated using enzymatic digestion with papain followed by OptiPrep (Accurate Chemical) gradient as described previously (Kerstetter and Miller, 2012). Neonatal spinal cord astrocytes were isolated using $0.25 \%$ trypsin, as described previously (Nijboer et al., 2013). Cells were cultured in a poly-L-lysine-coated 96-well plate in DMEM supplemented with $10 \%$ fetal calf serum (Invitrogen).

LPS (Sigma-Aldrich) was added to the culture medium at $100 \mathrm{ng} / \mathrm{ml}$ for astrocytes and $1 \mu \mathrm{g} / \mathrm{ml}$ for microglia in combination with human IL4-10 fusion protein or controls recombinant human IL4 and IL10 (Sigma-Aldrich). Receptor-blocking antibodies against mouse IL4 receptor or IL10 receptor (both BD PharMingen) were added at $2 \mu \mathrm{g} / \mathrm{ml}$. After $18 \mathrm{~h}$ of incubation at $37^{\circ} \mathrm{C}$, supernatant was collected and stored at $-80^{\circ} \mathrm{C}$. Glutamate uptake by spinal astrocytes was measured by incubating astrocytes in HBSS supplemented with $5 \mathrm{~mm}$ HEPES for $15 \mathrm{~min}$ at $37^{\circ} \mathrm{C}$. Uptake was started by adding $0.33 \mu \mathrm{Ci} / \mathrm{ml}$ of L-glutamate (GE Healthcare) mixed with unlabeled L-glutamate to a final concentration of $100 \mu \mathrm{M}$ (Sawada et al., 1999). After incubation of 0,3 , and $10 \mathrm{~min}$ at $37^{\circ} \mathrm{C}$, uptake was terminated by two washes with ice-cold HBSS, immediately followed by cell lysis with $0.1 \mathrm{~N} \mathrm{NaOH} / 0.01 \%$ SDS for 15 min on ice.

$m R N A$ isolation and real-time PCR. Whole lumbar DRGs and spinal cords (L3-L5) were homogenized in Trizol (Invitrogen). Total RNA was isolated with an RNeasy Mini Kit (Qiagen) and reverse transcribed using an iScript Select cDNA Synthesis Kit (Invitrogen). Real-time quantitative PCR was performed with an iQ SYBR Green Supermix (Invitrogen). Primer pairs used were as follows: IL1 $\beta$, CAACCAACAAGTGATATTCTCCATG (forward), GATCCACACTCTCCAGCTGCA (reverse); TNF $\alpha$, GCGGTGC CTATGTCTCAG (forward), GCCATTTGGGAACTTCTCATC (reverse); CCL2, GGTCCCTGTCATGCTTCTG (forward),CATCTTGCTGGT GAATGAGTAG (reverse); BDNF, CACATTACCTTCCAGCATCTGTTG (forward), ACCATAGTAAGGAAAAGGATGGTCAT (reverse); IL6, TCTAATTCATATCTTCAACCAAGAGG (forward), TGGTCCTTAGC CACTCCTTC(reverse); COX2, GGTCTGGTGCCTGGTCTG (forward),

\section{$\leftarrow$}

Figure 2. IL4-10 suppresses persistent inflammatory pain. Inflammatory pain was induced by an intraplantar injection of $20 \mu l$ of $2 \%$ carrageenan in mice. $\boldsymbol{a}-\boldsymbol{c}, \boldsymbol{e}-\boldsymbol{i}$, Thermal sensitivity was measured over time using the Hargreaves $(\mathrm{HG})$ test $(\boldsymbol{a}, \boldsymbol{f}, \boldsymbol{h})$, and mechanical hypersensitivity was measured using the von Frey (vF) test $(\boldsymbol{b}, \boldsymbol{c}, \boldsymbol{e}, \boldsymbol{g}, \boldsymbol{i}) \cdot \boldsymbol{a}, \boldsymbol{b}$, Six days after intraplantar injection, mice received intrathecal injections of different concentrations of IL4-10 fusion protein ( $n=6,14,6$, and 12 for $0,40,100$, and $200 \mathrm{ng}$, respectively). c, Six days after intraplantar injection, mice received an intraplantar injection of the IL4-10 fusion protein in one paw or vehicle in the other $(n=10)$, and mechanical hyper sensitivity followed. $\boldsymbol{d}$, The inflamed hindpaws were collected $2 \mathrm{~d}$ later and analyzed for mRNA expression for TNF $\alpha$, IL $1 \beta$, and KC and were normalized for GAPDH and $\beta$-actin. $\boldsymbol{e}$, Mice were exposed to an unilateral spared nerve injury (SNI), and mechanical sensitivity was analyzed. IL4-10 fusion protein was intrathecally injected (gray square) at days 6 and 7 after SNI $(n=4) . \boldsymbol{f}, \boldsymbol{g}$, The effectiveness of the IL4-10 fusion protein ( $100 \mathrm{ng} /$ mouse) to block inflammatory pain after intrathecal administration was compared with IL 4 or IL 10 alone ( $50 \mathrm{ng} / \mathrm{mouse})$ and IL 4 and IL $10(50+50 \mathrm{ng} / \mathrm{mouse})$ combined (HG, $n=16 ; \mathrm{vF}, n=8$ per group). The IL4-10 fusion protein blocks inflammatory pain more efficiently compared to the individual cytokines or the combination of IL4 and IL10. Asterisks mark statistical differences compared to vehicle-treated animals. $\boldsymbol{h}, \boldsymbol{i}$, The inhibitory effect of the IL4-10 fusion protein (100 ng/mouse) on inflammatory pain was attenuated in presence of receptor-blocking antibodies ( $6 \mu \mathrm{g} /$ mouse) against the IL 4 receptor ( $\alpha$ IL $4 R)$ and the IL 10 receptor $(\alpha \mid \mathrm{L} 10 \mathrm{R})$, demonstrating functional activity of both cytokine moieties and the requirement of both moieties for optimal effect $(n=8)$. Right, Area under curve ( $\triangle \mathrm{AUC})$ for the percentage of inhibition between 1 and $48 \mathrm{~h}$ after intrathecal injection. Asterisks mark statistical differences compared to vehicle-treated mice $(\boldsymbol{a}-\boldsymbol{d})$ or control lgG $(\boldsymbol{e}-\boldsymbol{f}) .{ }^{*} p<0.05 ;{ }^{* *} p<$ $0.01 ;{ }^{* * *} p<0.001$.
CTCTCCTATGAGTATGAGTCTGC (reverse); CCR2, ACCTGTAAAT GCCATGCAAGT (forward), TGTCTTCCATTTCCTTTGATTTG (reverse); CX3CR1, TGTCCACCTCCTTCCCTGAA (forward), TCGCCCA AATAACAGGCC (reverse); keratinocyte chemoattractant (KC), AAA AGGTGTCCCCAAGTAACG (forward), GTCAGAAGCCAGCGTT CAC (reverse); TGF $\beta 1$, CAGAGCTGCGCTTGCAGAG (forward), GTCAGCAGCCGGTTACCAAG (reverse); GAPDH, TGCGA CTTCA ACAGC AACTC (forward), CTTGC TCAGT GTCCT TGCTG (reverse); hypoxanthine guanine phosphoribosyl transferase, TCCTCCTCAGACCGCTTTT (forward), CCTGGTTCATCATCGCTAATC (reverse); $\beta$ actin, AGAGGGAAATCGTGCGTGAC (forward), CAATAGTGATGA CCTGGCCGT (reverse). Expression was normalized against GAPDH and hypoxanthine guanine phosphoribosyl transferase (spinal cords and DRGs) or GAPDH and $\beta$-actin (hindpaws).

Cytokine assessments. Supernatants were analyzed for TNF $\alpha$ by ELISA. Mouse TNF $\alpha$ production was measured using ELISA kits (mouse, TNFa DuoSet ELISA Kit; R \& D Systems), according to manufacturer's instructions and using the standards provided.

Statistical analysis. For all measurements, data are expressed as mean \pm SEM. Investigators performing the behavioral assays or assessing outcomes were blinded to treatment. Data were analyzed for statistical significance by one-way or two-way ANOVA with Bonferroni posttests where appropriate. A $p$ value of $<0.05$ was considered significant.

\section{Results}

\section{IL4-10 fusion protein characteristics}

Human IL4-10 fusion protein was produced by transient transfection of HEK293 cells (Durocher et al., 2002) and cotransfected with $\beta$-galactoside- $\alpha 2,3$-sialyltransferase to optimize glycancapping with sialic acid (Fig. 1a). In the supernatant of HEK293 cells expressing IL4-10 fusion protein, both IL4 and IL10 were detected (Fig. $1 b-e$ ). Wild-type (wt) IL4 and wt IL10 migrated with a molecular mass of $\sim 15 \mathrm{kDa}$ on SDS-PAGE gels, whereas IL4-10 migrated as two protein bands with a molecular mass of $\sim 30-35 \mathrm{kDa}$ that was detected by anti-IL4 and anti-IL10 (Fig. $1 f, g)$. The two bands represent glycoforms of IL4-10 fusion protein as they migrated as one band upon deglycosylation of the supernatant with PNGaseF (Fig. 1f,g). IL4-10 fusion protein was purified by cation exchange chromatography and analyzed by high-pressure size-exclusion chromatography. Wild-type IL4 eluted as a monomer with an apparent mass of $\sim 15 \mathrm{kDa}$, and wt IL10 as a dimer of $\sim 40 \mathrm{kDa}$, consistent with the notion that the active form of wt IL10 is a noncovalently linked dimer. IL4-10 fusion protein predominantly eluted with an apparent mass of $\sim 70 \mathrm{kDa}$, consistent with a noncovalently linked dimer (Fig. 1h).

\section{IL4-10 fusion protein inhibits persistent inflammatory pain}

The potential of IL4-10 fusion protein to inhibit persistent hyperalgesia was evaluated in the well-established murine model of carrageenan-induced persistent inflammatory pain (Ren and Dubner, 1999; Clapper et al., 2010; Eijkelkamp et al., 2010; Willemen et al., 2012). Intrathecal injection of $40 \mathrm{ng}$ IL4-10 fusion protein during persistent inflammatory pain significantly inhibited mechanical and thermal hyperalgesia during the first $24 \mathrm{~h}$ after administration. Increasing the dose of IL4-10 fusion protein increased the magnitude and duration of inhibition of persistent inflammatory hyperalgesia. At a dose of $200 \mathrm{ng}$, IL4-10 inhibited persistent inflammatory hyperalgesia for at least 2 (mechanical) to 4 (thermal) days (Fig. 2a,b). Intrathecal IL4-10 injection did not affect baseline thermal thresholds (vehicle, $7.9 \pm 0.2 \mathrm{~s}$; IL4-10 fusion protein, $8.3 \pm 0.2 \mathrm{~s}, n=10,24 \mathrm{~h}$ after injection) or mechanical thresholds (vehicle, $0.51 \pm 0.08$; IL4-10 fusion protein, $0.67 \pm 0.07, n=6,24 \mathrm{~h}$ after injection). Injection of $100 \mathrm{ng}$ IL4-10 into the inflamed paw, a dose that effectively inhibited persistent hyperalgesia when injected intrathecally, did not affect 


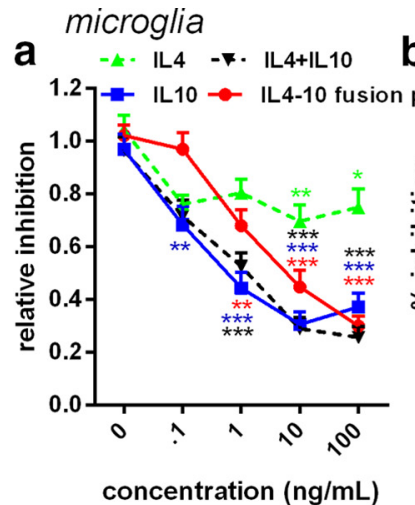

f

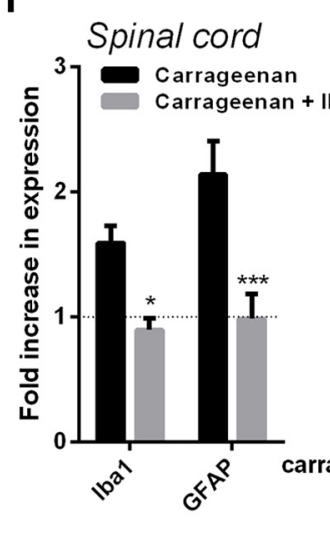

g

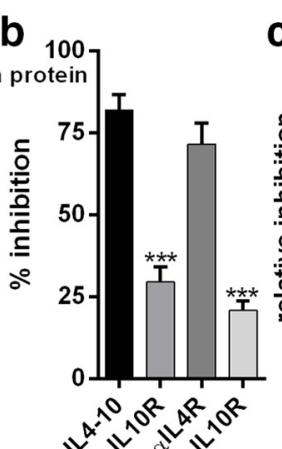

$v^{4}$
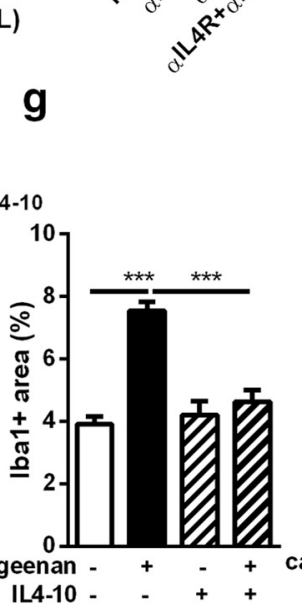

\section{astrocytes}

C $\rightarrow$ IL4 -F. IL4+IL10 d

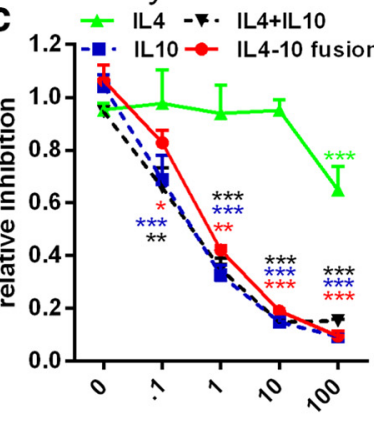

concentration $(\mathrm{ng} / \mathrm{mL})$
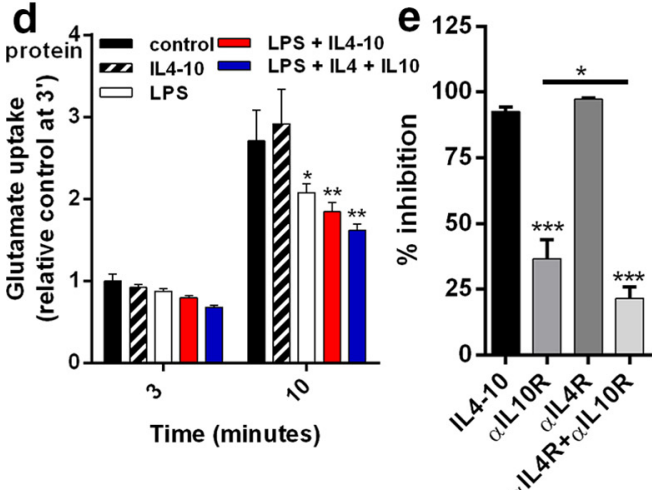

h
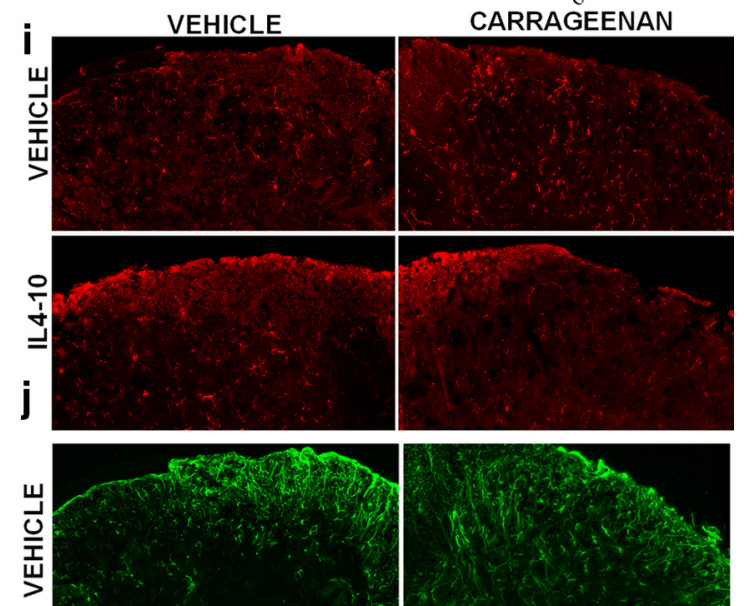

k
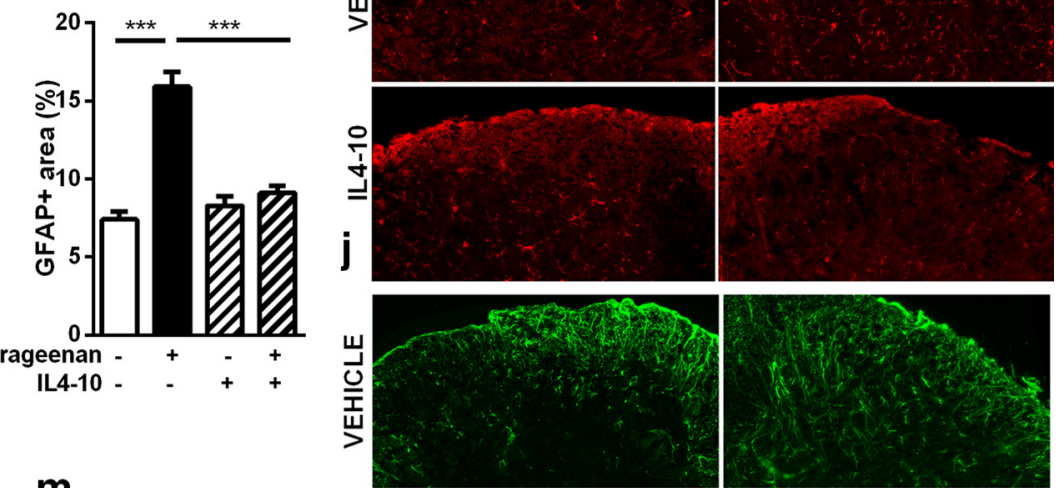

k Dorsal root ganglia |

m
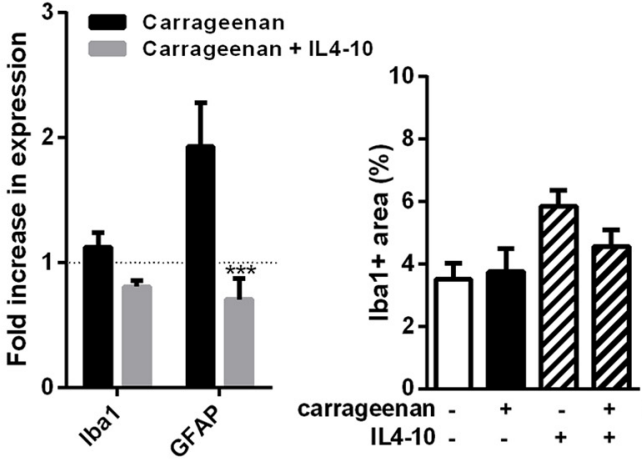

$\mathbf{0}$

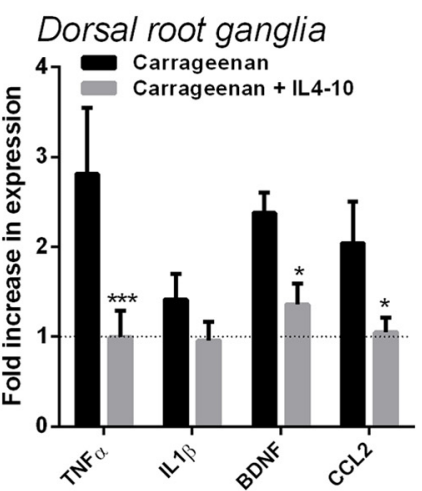

p

Spinal cord

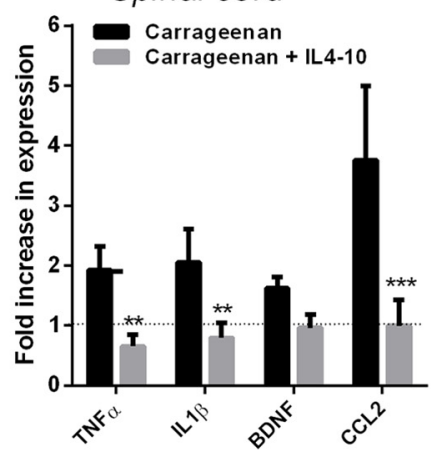

q Hindpaw
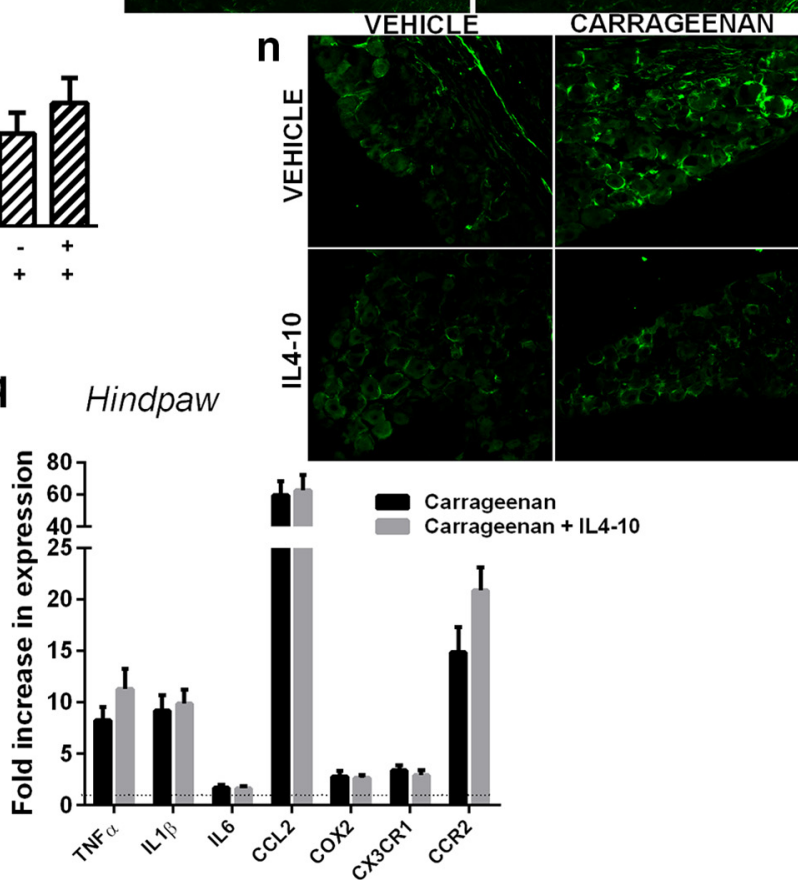

Figure 3. IL4-10 fusion protein inhibits neuroinflammation in spinal cord and dorsal root ganglia. $\boldsymbol{a}, \mathrm{lL} 4-10$ fusion protein dose-dependently inhibited LPS-induced (1 $\mu \mathrm{g} / \mathrm{ml})$ TNF $\alpha$ release by microglia $(n=17)$. $\boldsymbol{b}$, Requirement of the cytokine moieties of the IL4-10 fusion protein on LPS-induced TNF $\alpha$ release by spinal cord microglia $(n=10)$ was tested by adding receptor-blocking antibodies ( $2 \mu \mathrm{g} / \mathrm{ml}$ ) against the IL4 receptor ( $\alpha$ IL4R), the IL10 receptor ( $\alpha \mathrm{LL} 10 \mathrm{R})$, or both. c, IL4-10 fusion protein dose-dependently inhibited LPS-induced (100 $\mathrm{ng} / \mathrm{ml})$ TNF $\alpha$ release by spinal astrocytes ( $n=6-17$ per condition). $\boldsymbol{d}$, IL4-10 fusion protein did not affect glutamate uptake by spinal cord astrocytes nor prevent the LPS-induced reduction (Figure legend continues.) 
persistent inflammatory hyperalgesia (Fig. 2c). In contrast, expression of TNF $\alpha$ and KC (CXCL1) but not IL1 $\beta$ in the inflamed paw was reduced $48 \mathrm{~h}$ after intraplantar IL4-10 injection (Fig. $2 d$ ). These data indicate that intrathecal injections that target spinal cord and DRGs are required to inhibit persistent inflammatory pain.

To test whether IL4-10 fusion protein is also efficacious in a murine model of persistent neuropathic pain, we assessed its effect in the spared nerve injury model. Intrathecal administration of the IL4-10 fusion protein completely but transiently restored mechanical thresholds to control levels (Fig. 2e). IL4-10 did not affect the mechanical threshold in the unaffected contralateral paw (Fig. 2e).

To determine whether IL4-10 fusion protein has increased efficacy in inhibiting persistent inflammatory pain as compared with the native cytokines, we compared it with native cytokines either as stand-alone or combination therapy. Intrathecal administration of IL4 or IL10 alone had a statistically significant but small transient inhibitory effect on persistent hyperalgesia (Fig. $2 f, g$ ). An equimolar dose of IL4-10 was significantly more potent in inhibiting persistent inflammatory hyperalgesia, compared with IL4 or IL10 alone. In addition, the IL4-10 fusion protein was still more effective in treating pain than a double concentration of IL4 plus IL10 (data not shown). The combination of IL4 and IL10 partially inhibited persistent hyperalgesia and had a larger effect than the stand-alone cytokines, indicating a synergistic or additive effect of the two regulatory cytokines in inhibiting persistent pain (Fig. $2 f, g$ ). However, the fusion protein IL4-10 completely inhibited persistent inflammatory hyperalgesia for at least $2 \mathrm{~d}$, whereas the combination of IL4 and IL10 only partially inhibited this hyperalgesia $(\sim 45 \%)$, and for a much shorter period of time $(<1 \mathrm{~d})$, indicating that IL4-10 has superior efficacy over IL4 and IL10 combination therapy. Coinjection of the fusion protein IL4-10 with antibodies blocking either IL10 or IL4 receptor antibodies reduced the beneficial effect of IL4-10 on persistent pain (Fig. $2 h, i$ ), indicating that both cytokine moieties of IL4-10 are required for maximal efficacy.

\section{IL4-10 fusion protein inhibits neuroinflammation}

Rodent models for chronic pain and human data support a role for glial cells in different chronic pain states (Brisby et al., 1999;

\footnotetext{
$\leftarrow$

(Figure legend continued.) in glutamate uptake $(n=9) . \boldsymbol{e}$, Requirement of the cytokine moieties to inhibit LPS-induced TNF $\alpha$ release by spinal astrocytes $(n=8)$. $\boldsymbol{f}-\boldsymbol{p}$, Persistent inflammatory pain was induced by an intraplantar injection of carrageenan $(20 \mu \mathrm{l}, 2 \%)$, and $6 \mathrm{~d}$ later mice were treated intrathecally with vehicle (PBS) or fusion protein ( $100 \mathrm{ng} / \mathrm{mouse})$. One day after fusion protein application, glial cell activation in the spinal cord $(\boldsymbol{f}-\boldsymbol{j})$ and dorsal root ganglia $(\boldsymbol{k}-\boldsymbol{n})$ was assessed by analyses of spinal cord mRNA encoding for Iba1 (microglia) and GFAP (astrocytes; $f$ ). Data are expressed as fold induction compared to the saline-treated groups $(n=10) \cdot \boldsymbol{g}-\boldsymbol{j}$, One day after fusion protein application, the extent of glial cell activation was quantified by determining the lba1-positive $(\boldsymbol{g})$ and GFAP-positive $(\boldsymbol{h})$ areas in the dorsal horn of the lumbar spinal cord for, respectively, microglia/macrophages and astrocytes (no carrageenan, $n=3$ /group; carrageenan, $n=7$ ). Exemplar images of the Iba1 (i) and GFAP (j) staining quantified in $\boldsymbol{g}$ and $\boldsymbol{h}$. $\boldsymbol{k}$, Fold induction of mRNA for Iba1 and GFAP in the DRGs compared to the saline-treated groups (without carrageenan). $\boldsymbol{i}-\boldsymbol{m}$, Quantification of the Iba1positive $(\boldsymbol{I})$ and GFAP-positive $(\boldsymbol{m})$ areas in the DRGs. $\boldsymbol{n}$, Exemplar images of GFAP expression in the DRGs quantified in $\boldsymbol{m} . \boldsymbol{o}, \boldsymbol{p}$, Mice received intraplantar injection of carrageenan or saline, and $6 \mathrm{~d}$ later mice were treated with either PBS or IL4-10 fusion protein ( $100 \mathrm{ng} / \mathrm{mouse}, n=10$ per group). Lumbar DRGs $(\boldsymbol{o})$, lumbar spinal cords $(\boldsymbol{p})$, and inflamed hindpaws $(\boldsymbol{q})$ were collected $1 \mathrm{~d}$ later and analyzed for mRNA expression for several cytokines, chemokines, growth factors, and/or chemokine receptors and normalized for GAPDH and $\beta$-actin or hypoxanthine guanine phosphoribosyl transferase. Data are expressed as fold induction compared with the salinetreated groups. All data are expressed as mean \pm SEM. ${ }^{*} p<0.05 ;{ }^{* *} p<0.01$; ${ }^{* * *} p<0.001$.
}

Banati et al., 2001; Del Valle et al., 2009; Graeber and Christie, 2012; Shi et al., 2012; Ji et al., 2013; Loggia et al., 2015). Activated glial cells in the dorsal horn of the spinal cord and infiltrating macrophages or activated satellite glial cells in the DRG produce proinflammatory cytokines that sensitize the sensory system (Ren and Dubner, 2010). IL4-10 fusion protein dosedependently inhibited LPS-induced TNF $\alpha$ release by isolated primary spinal cord microglia (Fig. 3a). IL4-10 was equally efficient compared to IL10 alone or IL10 and IL4 combined. IL4 only moderately inhibited LPS-induced TNF $\alpha$ production by spinal microglia. In spinal microglia, inhibition of LPS-induced TNF $\alpha$ release by IL4-10 was completely reversed by a blocking antibody against the IL10R, but not by blocking the IL4R (Fig. $3 b$ ). Combining IL4 and IL10 receptor-blocking antibodies did not further prevent the inhibitory effect of IL4-10 compared with only IL10R-blocking antibodies, indicating that IL4-10-mediated inhibition of microglial activity mainly depended on the IL10 moiety (Fig. 3b). Spinal cord astrocytes also produced TNF $\alpha$ after LPS stimulation that was dose-dependently inhibited by IL4-10 fusion protein (Fig. 3c). IL4-10 inhibited TNF $\alpha$ release to a similar extent as IL10 or IL4 and IL10 combined (Fig. 3c), whereas IL4 only moderately reduced this release.

Impaired astrocyte glutamate transporter function leads to excessive glutamate receptor stimulation and is implicated in pathological pain states (Nie and Weng, 2010; Weng et al., 2014; Yan et al., 2014). LPS reduced glutamate uptake by primary spinal astrocytes, but this was not affected by IL4-10 (Fig. $3 d$ ). Thus, IL4-10 effectively attenuated inflammatory responses of glial cells without affecting their capacity to take up glutamate. In astrocytes, the IL10 receptor-blocking antibody partially reduced the inhibitory effect of IL4-10 on LPS-induced TNF $\alpha$ release. Blocking IL4R was insufficient to attenuate the inhibitory effect of IL4-10, but blocking both IL4 and IL10 receptors prevented IL410-mediated inhibition to a greater extent, versus blocking the IL10R alone (Fig. 3e). Thus, inhibition of astrocytes by IL4-10 is dependent on the biological activity of both cytokine moieties.

To define whether inhibition of persistent inflammatory pain is also associated with a reduction in glial cell activation in vivo, Iba1 and GFAP expression were quantified as measures of microglia and astrocyte/satellite cell activation in spinal cord or satellite glial cell and macrophage activation in the DRG (Ji et al., 2013). Carrageenan-induced persistent inflammation increased Iba1 mRNA expression (Fig. $3 f$ ) and the Iba1-positive area (Fig. 3g,i) in the spinal cord. Importantly, intrathecal IL4-10 treatment attenuated the carrageenan-induced increase in spinal cord Ibal mRNA expression (Fig. $3 f$ ) and the Iba1-positive area in the dorsal horn of the spinal cord (Fig. $3 g, i$ ). Ibal mRNA expression or Iba1-positive area in the DRG was not affected after intraplantar carrageenan injection or IL4-10 treatment (Fig. $3 k, l$ ). GFAP expression in the dorsal horn of the spinal cord and DRG was increased after intraplantar carrageenan injection at the level of mRNA (Fig. $3 f, k$ ) and the GFAP-positive area $(h, j, m, n)$. IL4-10 potently reduced GFAP expression in both spinal cord (Fig. $3 f, h, j)$ and DRG (Fig. $3 k, m, n)$.

We verified whether the inhibition of glial cell activity in spinal cord and DRG was associated with reduced cytokine expression. IL4-10 fusion protein attenuated carrageenan-induced mRNA for TNF $\alpha$, CCL2, and BDNF in the DRG (Fig. 3o). In the spinal cord, IL4-10 inhibited the carrageenan-induced expression of IL1 $\beta$, TNF $\alpha$, and CCL2 (Fig. $3 p$ ). These data indicate that IL4-10 fusion protein inhibits inflammatory response in the spinal cord and DRGs during persistent inflammatory pain. 


\section{carrageenan}

a

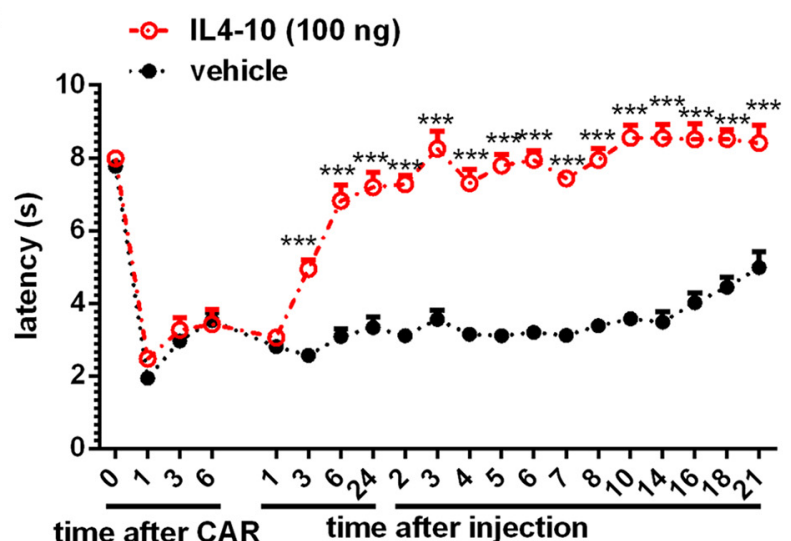

(days)

(h)

(days) b

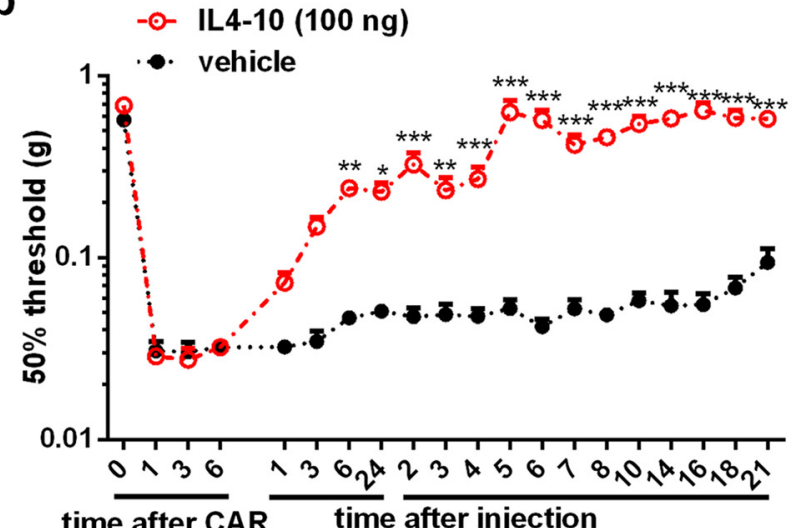

(days)

(days)

\section{CFA}

C -๑- Veh contralateral: veh $\cdot \odot \cdot$ Veh contralateral: IL4-10 (100 ng) $\rightarrow$ CFA ipsilateral: veh $\rightarrow$ CFA ipsilateral: IL4-10 (100 ng)

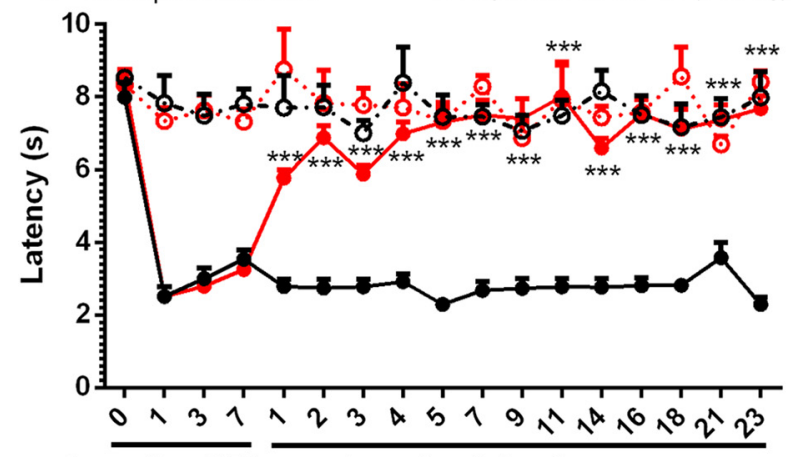

time after CFA time after injection (days)

e

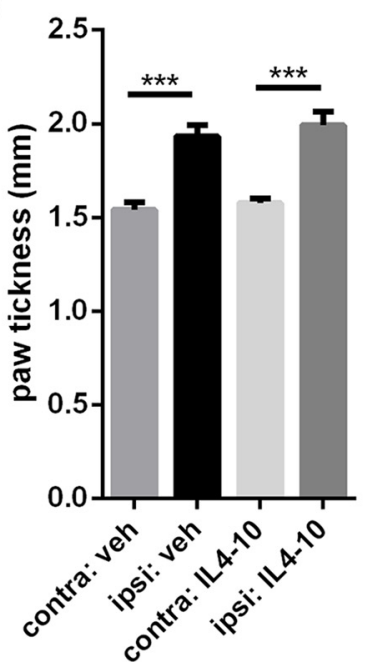

(days)

f

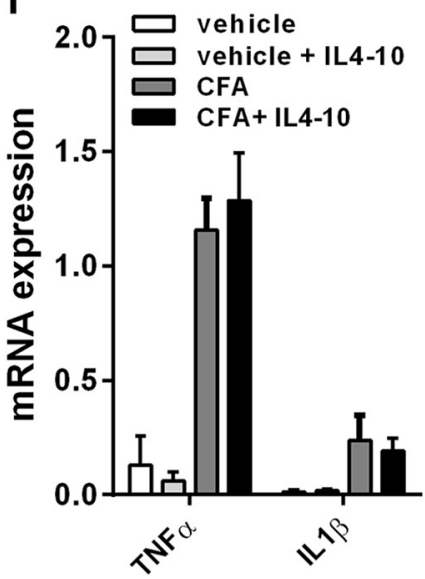

d -๑- Veh contralateral: veh .๑. Veh contralateral: IL4-10 (100 ng)

$\rightarrow$ CFA ipsilateral: veh $\rightarrow$ CFA ipsilateral: IL4-10 (100 ng)

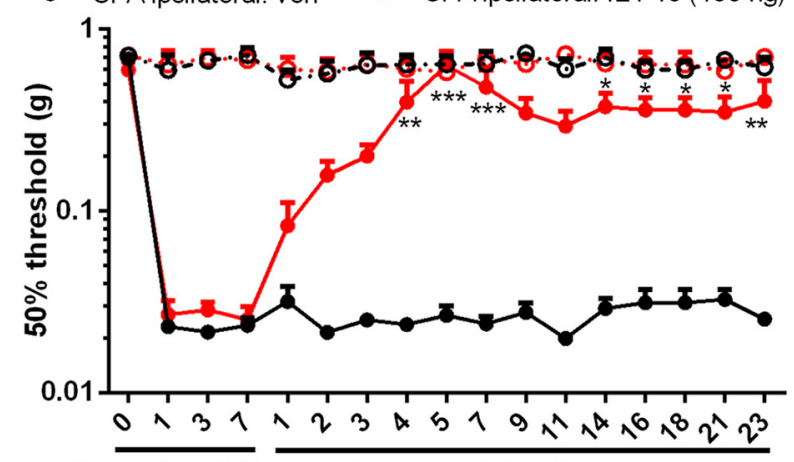

time after CFA time after injection (days)

(days)

\section{g}

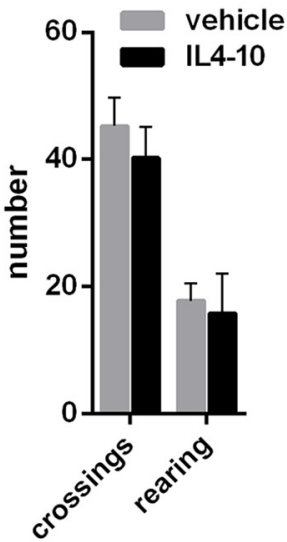

Figure 4. Repeated IL4-10 fusion protein injections completely resolves inflammatory pain. $\boldsymbol{a}-\boldsymbol{d}$, Inflammatory pain was induced by an intraplantar injection of $20 \mu \mathrm{l}, 2 \%$ carrageenan $(\boldsymbol{a}, \boldsymbol{b})$ or a unilateral injection of $20 \mu \mathrm{ICFA}$ in mice $(\boldsymbol{c}, \boldsymbol{d})$, and thermal sensitivity $(\boldsymbol{a}, \boldsymbol{c})$ and mechanical hypersensitivity $(\boldsymbol{b}, \boldsymbol{d})$ followed over time. At 6, 8, and $10 \mathrm{~d}($ carrageenan, $n=8)$ or 7,9 , and $11 \mathrm{~d}(\mathrm{CFA}$, $n=5$ ) after intraplantar injection, mice received intrathecal injections of IL4-10 fusion protein (100 ng) or vehicle (veh). $\boldsymbol{e}, \boldsymbol{f}$, Paw edema in CFA-injected and vehicle-injected hindpaws was measured using a digital micrometer 5 weeks after intraplantar injection $(\boldsymbol{e})$ and subsequently collected and analyzed for mRNA expression ( $\boldsymbol{f}$ ) for TNF $\alpha$ and IL1 $\beta$ and normalized for GAPDH and $\beta$-actin. $\boldsymbol{g}$, To assess whether multiple injections of IL4-10 fusion protein affect motor behavior, mice were assessed in an open field after three intrathecal injections, and the number of crossing and rearing were counted in a 5 min interval. ${ }^{*} p<0.05 ;{ }^{* *} p<0.01 ;{ }^{* * *} p<0.001$ (vs vehicle-treated mice). 
To verify whether IL4-10 fusion protein treatment affected the local inflammatory response in the hindpaw, we performed qPCR on paw tissue $24 \mathrm{~h}$ after intrathecal IL4-10 treatment. Carrageenan-induced expression of IL1 $\beta$, TNF $\alpha$, IL6, CCL2, COX2, and the chemokine receptors CX3CR1 and CCR2, which are highly expressed on macrophages, were not affected by intrathecal administration of IL4-10 fusion protein (Fig. 3q). These data show that IL4-10 fusion protein inhibits spinal/DRG neuroinflammation and inflammatory pain without modifying the peripheral inflammatory response.

\section{Multiple IL4-10 fusion protein administration induces full resolution of inflammatory pain}

To further evaluate the therapeutic potential of the IL4-10 fusion protein, we tested whether multiple intrathecal injections with IL4-10 induced full resolution of inflammatory pain in two different models of persistent inflammatory pain. Three intrathecal injections of the IL4-10 fusion protein every other day completely reversed carrageenan-induced hyperalgesia, which persists for weeks without treatment. No hyperalgesia was observed for the complete observation period of 2 weeks after the first IL4-10 treatment (Fig. 4a,b).

A comparable effect of the IL4-10 fusion protein was observed in another well-established persistent inflammatory pain model, i.e., mice receiving an intraplantar injection of CFA (Ren and Dubner, 1999). Intrathecal injection of IL4-10 fusion protein 7, 9, and $11 \mathrm{~d}$ after the intraplantar CFA injection completely and persistently resolved the inflammatory thermal and mechanical hyperalgesia (Fig. $4 c, d$ ), whereas the inflammatory response in the affected paw was unaltered (Fig. 4e,f). Notably, the multiple intrathecal injections of the human IL4-10 fusion protein did not induce detectable antibodies against IL4-10 fusion protein, as examined 3 weeks after the last intrathecal injections (data not shown). Multiple intrathecal injections of IL4-10 fusion protein or vehicle did not affect spontaneous locomotor activity (Fig. 4g). Overall, these data illustrate the potential of the IL4-10 fusion protein to fully resolve persistent inflammatory pain.

\section{Discussion}

Here, we describe a new approach to treat persistent inflammatory pain using a fusion protein of the regulatory cytokines IL4 and IL10. We found that three intrathecal doses of this IL4-IL10 fusion protein completely resolved persistent inflammatory pain in two mouse models and inhibited neuroinflammatory response in the dorsal root ganglia and spinal cord, without affecting paw inflammation. The IL4-10 fusion protein also inhibited neuropathic pain. Biochemical and functional characterization of the IL4-10 fusion protein revealed that the full biological activity of its two cytokine moieties are retained, as assessed in vitro and in vivo.

Thus far, there is very limited evidence for sustained therapeutic effects of intrathecal administration of cytokines like IL10 (Dengler et al., 2014). Here, we show that the IL4-10 fusion protein overcomes this limitation. The efficacy of IL4-10 to reverse persistent inflammatory pain was superior in duration and in magnitude compared with the individual cytokines or even the combination of free IL4 and free IL10. Three intrathecal injections of IL4-10 fully and permanently reversed persistent inflammatory hyperalgesia in two models without affecting inflammatory response in the hindpaws.

The IL4-10 fusion protein has multiple advantages over individual cytokines to treat pain. IL4 and IL10 act through different mechanisms: IL4 primarily increases degradation of proinflam- matory cytokine mRNA, whereas IL10 primarily inhibits transcription (Wang et al., 1995). These complementary mechanisms of action explain why IL4 and IL10 can act synergistically (van Roon et al., 1996, 2001; Joosten et al., 1997). Indeed, in vivo, combination therapy with IL4 and IL10 was more effective than treatment with the individual cytokines in attenuating persistent inflammatory pain, suggesting additive or synergistic activities. Consistently, maximal efficacy to reduce pain with IL4-10 required the activity of both cytokine moieties; blocking antibodies against either the IL4 or the IL10 receptor reduced the beneficial effects of the IL4-IL10 fusion protein.

Incorporation of the two cytokines into one fusion protein increases the molecular size without impairing the tendency of the IL10 moiety to dimerize. Because of its larger molecular size, the IL4-10 fusion protein likely has a better bioavailability than the separate cytokines. It is likely that increased bioavailability contributes to the increased efficacy of the fusion protein versus the mixture of free IL4 and IL10 in reducing pain. Thus, the strategy of incorporating IL4 and IL10 into one protein overcomes some of the limitations associated with the use of IL4 and IL10 as stand-alone therapies. Moreover, by using the cytokine fusion approach, we avoid problems linked to viral gene therapy and the nonviral transduction vectors used to induce prolonged production of native cytokines (Cunha et al., 1999; Vale et al., 2003; Milligan et al., 2005; Hao et al., 2006; Soderquist et al., 2010; Dengler et al., 2014). In addition, direct protein administration intrathecally is advantageous over viral therapy because it is effective immediately and avoids potential unwanted systemic effects.

Chronic pain in inflammatory diseases, such as rheumatoid arthritis, is frequently disconnected from peripheral inflammation. For example, disease-modifying antirheumatic drugs reduce disease activity, yet a large proportion of patients continue to report moderate to severe pain (Kojima et al., 2009; American College of Rheumatology Pain Management Task Force, 2010). We here report that single or multiple injections of the IL4-10 fusion protein into the spinal compartment inhibited persistent pain without affecting the local peripheral inflammatory response that induced the pain. Conversely, intraplantar injection of IL4-10 into the inflamed hindpaw reduced inflammatory responses, but without affecting the ongoing hyperalgesia. These are important findings because they highlight that persistent pain induced by peripheral inflammation can continue independently of ongoing peripheral inflammation. More than $60 \%$ of patients with rheumatoid arthritis report unacceptable pain levels, indicating the pain is insufficiently controlled by the antirheumatic drugs and antipain medications these patient take. Interestingly, even when the response rates to the antirheumatic drug on the basis of European League Against Rheumatism criteria is good, patients can still complain of pain (Taylor et al., 2010). In these situations, targeting the inflammation in the CNS rather than in the joints may contribute to resolution of pain, because it directly targets pathological pain at the core of its driving mechanism.

We showed that both cytokine moieties of the IL4-10 fusion protein contribute to optimal pain inhibition in vivo. In vitro experiments revealed that the effect of the fusion protein on primary cultures of spinal cord microglia is mainly mediated via the IL10 moiety, whereas optimal inhibition of cytokine production by spinal astrocytes requires both cytokine moieties. Probably some effects of IL4-10 in vivo are mediated via cells other than glial cells. For example, immune cells that migrate to DRG and contribute to persistent pain states are strongly regulated by both IL4 and IL10 (Willemen et al., 2014; Kiguchi et al., 2015; Massier et al., 2015; Sorge et al., 2015). Other studies have shown that IL10 
controls sensory neuron activity, and IL4-deficient mice show enhanced spinal neuron excitability (Shen et al., 2013; Lemmer et al., 2015). Thus, IL4-10 could have its effect through neurons, in addition to its inhibitory effects on glial cells. The potential neuronal effects of IL4-10 are currently the subject of future studies.

In conclusion, we have developed a novel neuroimmune regulatory drug consisting of IL4 and IL10 that overcomes some of the limitations of IL4 and IL10 as stand-alone therapies. Its remarkable potency in inhibiting inflammatory pain in multiple models supports the potential of the IL4-10 fusion protein for the treatment of pain and possibly other symptoms of chronic inflammatory disease in humans.

\section{References}

American College of Rheumatology Pain Management Task Force (2010) Report of the American College of Rheumatology Pain Management Task Force. Arthritis Care Res (Hoboken) 62:590-599. CrossRef

Balasingam V, Yong VW (1996) Attenuation of astroglial reactivity by interleukin-10. J Neurosci 16:2945-2955. Medline

Banati RB, Cagnin A, Brooks DJ, Gunn RN, Myers R, Jones T, Birch R, Anand P (2001) Long-term trans-synaptic glial responses in the human thalamus after peripheral nerve injury. Neuroreport 12:3439-3442. CrossRef Medline

Bielefeldt K, Davis B, Binion DG (2009) Pain and inflammatory bowel disease. Inflamm Bowel Dis 15:778-788. CrossRef Medline

Borsook D, Hargreaves R, Bountra C, Porreca F (2014) Lost but making progress-where will new analgesic drugs come from? Sci Transl Med 6:249sr3. CrossRef Medline

Breivik H, Collett B, Ventafridda V, Cohen R, Gallacher D (2006) Survey of chronic pain in Europe: prevalence, impact on daily life, and treatment. Eur J Pain 10:287-333. CrossRef Medline

Brisby H, Olmarker K, Rosengren L, Cederlund CG, Rydevik B (1999) Markers of nerve tissue injury in the cerebrospinal fluid in patients with lumbar disc herniation and sciatica. Spine (Phila Pa 1976) 24:742-746. CrossRef

Chaplan SR, Bach FW, Pogrel JW, Chung JM, Yaksh TL (1994) Quantitative assessment of tactile allodynia in the rat paw. J Neurosci Methods 53: 55-63. CrossRef Medline

Clapper JR, Moreno-Sanz G, Russo R, Guijarro A, Vacondio F, Duranti A, Tontini A, Sanchini S, Sciolino NR, Spradley JM, Hohmann AG, Calignano A, Mor M, Tarzia G, Piomelli D (2010) Anandamide suppresses pain initiation through a peripheral endocannabinoid mechanism. Nat Neurosci 13:1265-1270. CrossRef Medline

Cunha FQ, Poole S, Lorenzetti BB, Veiga FH, Ferreira SH (1999) Cytokinemediated inflammatory hyperalgesia limited by interleukin-4. Br J Pharmacol 126:45-50. CrossRef Medline

Del Valle L, Schwartzman RJ, Alexander G (2009) Spinal cord histopathological alterations in a patient with longstanding complex regional pain syndrome. Brain Behav Immun 23:85-91. CrossRef Medline

Dengler EC, Alberti LA, Bowman BN, Kerwin AA, Wilkerson JL, Moezzi DR, Limanovich E, Wallace JA, Milligan ED (2014) Improvement of spinal non-viral IL-10 gene delivery by D-mannose as a transgene adjuvant to control chronic neuropathic pain. J Neuroinflammation 11:92. CrossRef Medline

Durocher Y, Perret S, Kamen A (2002) High-level and high-throughput recombinant protein production by transient transfection of suspensiongrowing human 293-EBNA1 cells. Nucleic Acids Res 30:E9. CrossRef Medline

Eijkelkamp N, Heijnen CJ, Willemen HL, Deumens R, Joosten EA, Kleibeuker W, den Hartog IJ, van Velthoven CT, Nijboer C, Nassar MA, Dorn GW 2nd, Wood JN, Kavelaars A (2010) GRK2: a novel cell-specific regulator of severity and duration of inflammatory pain. J Neurosci 30 : 2138-2149. CrossRef Medline

Eijkelkamp N, Linley JE, Torres JM, Bee L, Dickenson AH, Gringhuis M, Minett MS, Hong GS, Lee E, Oh U, Ishikawa Y, Zwartkuis FJ, Cox JJ, Wood JN (2013) A role for Piezo2 in EPAC1-dependent mechanical allodynia. Nat Commun 4:1682. CrossRef Medline

Graeber MB, Christie MJ (2012) Multiple mechanisms of microglia: a gatekeeper's contribution to pain states. Exp Neurol 234:255-261. CrossRef Medline

Hao S, Mata M, Glorioso JC, Fink DJ (2006) HSV-mediated expression of interleukin-4 in dorsal root ganglion neurons reduces neuropathic pain. Mol Pain 2:6. CrossRef Medline

Hargreaves K, Dubner R, Brown F, Flores C, Joris J (1988) A new and sensitive method for measuring thermal nociception in cutaneous hyperalgesia. Pain 32:77-88. CrossRef Medline

Institute of Medicine (US) Committee on Advancing Pain Research (2011) Relieving pain in America: a blueprint for transforming prevention, care, education, and research. Washington, DC: National Academies.

Ji RR, Berta T, Nedergaard M (2013) Glia and pain: is chronic pain a gliopathy? Pain 154 [Suppl 1]:S10-S28. Medline

Ji RR, Xu ZZ, Gao YJ (2014) Emerging targets in neuroinflammation-driven chronic pain. Nat Rev Drug Discov 13:533-548. CrossRef Medline

Joosten LA, Lubberts E, Durez P, Helsen MM, Jacobs MJ, Goldman M, van den Berg WB (1997) Role of interleukin-4 and interleukin-10 in murine collagen-induced arthritis. Protective effect of interleukin- 4 and interleukin-10 treatment on cartilage destruction. Arthritis Rheum 40:249-260. CrossRef Medline

Kerstetter AE, Miller RH (2012) Isolation and culture of spinal cord astrocytes. Methods Mol Biol 814:93-104. CrossRef Medline

Kiguchi N, Kobayashi Y, Saika F, Sakaguchi H, Maeda T, Kishioka S (2015) Peripheral interleukin-4 ameliorates inflammatory macrophage-dependent neuropathic pain. Pain 156:684-693. CrossRef Medline

Kloss CU, Kreutzberg GW, Raivich G (1997) Proliferation of ramified microglia on an astrocyte monolayer: characterization of stimulatory and inhibitory cytokines. J Neurosci Res 49:248-254. Medline

Kojima M, Kojima T, Suzuki S, Oguchi T, Oba M, Tsuchiya H, Sugiura F, Kanayama Y, Furukawa TA, Tokudome S, Ishiguro N (2009) Depression, inflammation, and pain in patients with rheumatoid arthritis. Arthritis Rheum 61:1018-1024. CrossRef Medline

Kwilasz AJ, Grace PM, Serbedzija P, Maier SF, Watkins LR (2015) The therapeutic potential of interleukin-10 in neuroimmune diseases. Neuropharmacology 96:55-69. CrossRef Medline

Lee YC, Cui J, Lu B, Frits ML, Iannaccone CK, Shadick NA, Weinblatt ME, Solomon DH (2011) Pain persists in DAS28 rheumatoid arthritis remission but not in ACR/EULAR remission: a longitudinal observational study. Arthritis Res Ther 13:R83. CrossRef Medline

Lemmer S, Schießer P, Geis C, Sommer C, Vanegas H, Üçeyler N (2015) Enhanced spinal neuronal responses as a mechanism for the increased nociceptive sensitivity of interleukin-4 deficient mice. Exp Neurol 271: 198-204. CrossRef Medline

Lodge PA, Sriram S (1996) Regulation of microglial activation by TGF-beta, IL-10, and CSF-1. J Leukoc Biol 60:502-508. Medline

Loggia ML, Chonde DB, Akeju O, Arabasz G, Catana C, Edwards RR, Hill E, Hsu S, Izquierdo-Garcia D, Ji RR, Riley M, Wasan AD, Zürcher NR, Albrecht DS, Vangel MG, Rosen BR, Napadow V, Hooker JM (2015) Evidence for brain glial activation in chronic pain patients. Brain 138: 604-615. CrossRef Medline

Lomholt JJ, Thastum M, Herlin T (2013) Pain experience in children with juvenile idiopathic arthritis treated with anti-TNF agents compared to non-biologic standard treatment. Pediatr Rheumatol Online J 11:21. CrossRef Medline

Massier J, Eitner A, Segond von Banchet G, Schaible HG (2015) Effects of differently activated rodent macrophages on sensory neurons: implications for arthritis pain. Arthritis Rheumatol 67:2263-2272. CrossRef Medline

Milligan ED, Langer SJ, Sloane EM, He L, Wieseler-Frank J, O'Connor K, Martin D, Forsayeth JR, Maier SF, Johnson K, Chavez RA, Leinwand LA, Watkins LR (2005) Controlling pathological pain by adenovirally driven spinal production of the anti-inflammatory cytokine, interleukin10. Eur J Neurosci 21:2136-2148. CrossRef Medline

Nie H, Weng HR (2010) Impaired glial glutamate uptake induces extrasynaptic glutamate spillover in the spinal sensory synapses of neuropathic rats. J Neurophysiol 103:2570-2580. CrossRef Medline

Nijboer CH, Heijnen CJ, Degos V, Willemen HL, Gressens P, Kavelaars A (2013) Astrocyte GRK2 as a novel regulator of glutamate transport and brain damage. Neurobiol Dis 54:206-215. CrossRef Medline

Pepe G, Calderazzi G, De Maglie M, Villa AM, Vegeto E (2014) Heterogeneous induction of microglia M2a phenotype by central administration of interleukin-4. J Neuroinflammation 11:211. CrossRef Medline

Ren K, Dubner R (1999) Inflammatory Models of Pain and Hyperalgesia. ILAR J 40:111-118. CrossRef Medline 
Ren K, Dubner R (2010) Interactions between the immune and nervous systems in pain. Nat Med 16:1267-1276. CrossRef Medline

Sawada M, Suzumura A, Hosoya H, Marunouchi T, Nagatsu T (1999) Interleukin-10 inhibits both production of cytokines and expression of cytokine receptors in microglia. J Neurochem 72:1466-1471. Medline

Shen KF, Zhu HQ, Wei XH, Wang J, Li YY, Pang RP, Liu XG (2013) Interleukin-10 down-regulates voltage gated sodium channels in rat dorsal root ganglion neurons. Exp Neurol 247:466-475. CrossRef Medline

Shi Y, Gelman BB, Lisinicchia JG, Tang SJ (2012) Chronic-pain-associated astrocytic reaction in the spinal cord dorsal horn of human immunodeficiency virus-infected patients. J Neurosci 32:10833-10840. CrossRef Medline

Soderquist RG, Milligan ED, Harrison JA, Chavez RA, Johnson KW, Watkins LR, Mahoney MJ (2010) PEGylation of interleukin-10 for the mitigation of enhanced pain states. J Biomed Mater Res A 93:1169-1179. Medline

Sorge RE, Mapplebeck JC, Rosen S, Beggs S, Taves S, Alexander JK, Martin LJ, Austin JS, Sotocinal SG, Chen D, Yang M, Shi XQ, Huang H, Pillon NJ, Bilan PJ, Tu Y, Klip A, Ji RR, Zhang J, Salter MW, et al. (2015) Different immune cells mediate mechanical pain hypersensitivity in male and female mice. Nat Neurosci 18:1081-1083. CrossRef Medline

Taylor P, Manger B, Alvaro-Gracia J, Johnstone R, Gomez-Reino J, Eberhardt E, Wolfe F, Schwartzman S, Furfaro N, Kavanaugh A (2010) Patient perceptions concerning pain management in the treatment of rheumatoid arthritis. J Int Med Res 38:1213-1224. CrossRef Medline

Vale ML, Marques JB, Moreira CA, Rocha FA, Ferreira SH, Poole S, Cunha FQ, Ribeiro RA (2003) Antinociceptive effects of interleukin-4, -10, and -13 on the writhing response in mice and zymosan-induced knee joint incapacitation in rats. J Pharmacol Exp Ther 304:102-108. CrossRef Medline

van Roon JA, van Roy JL, Gmelig-Meyling FH, Lafeber FP, Bijlsma JW (1996) Prevention and reversal of cartilage degradation in rheumatoid arthritis by interleukin-10 and interleukin-4. Arthritis Rheum 39:829835. CrossRef Medline

van Roon JA, Lafeber FP, Bijlsma JW (2001) Synergistic activity of interleukin-4 and interleukin-10 in suppression of inflammation and joint destruction in rheumatoid arthritis. Arthritis Rheum 44:3-12. CrossRef Medline

Wang P, Wu P, Siegel MI, Egan RW, Billah MM (1995) Interleukin (IL)-10 inhibits nuclear factor kappa B (NF kappa B) activation in human monocytes. IL-10 and IL-4 suppress cytokine synthesis by different mechanisms. J Biol Chem 270:9558-9563. CrossRef Medline

Weng HR, Gao M, Maixner DW (2014) Glycogen synthase kinase 3 beta regulates glial glutamate transporter protein expression in the spinal dorsal horn in rats with neuropathic pain. Exp Neurol 252:18-27. CrossRef Medline

Willemen HL, Huo XJ, Mao-Ying QL, Zijlstra J, Heijnen CJ, Kavelaars A (2012) MicroRNA-124 as a novel treatment for persistent hyperalgesia. J Neuroinflammation 9:143. CrossRef Medline

Willemen HL, Eijkelkamp N, Garza Carbajal A, Wang H, Mack M, Zijlstra J, Heijnen CJ, Kavelaars A (2014) Monocytes/Macrophages control resolution of transient inflammatory pain. J Pain 15:496-506. CrossRef Medline

Yan X, Yadav R, Gao M, Weng HR (2014) Interleukin-1 beta enhances endocytosis of glial glutamate transporters in the spinal dorsal horn through activating protein kinase C. Glia 62:1093-1109. CrossRef Medline

Yip PK, Kaan TK, Fenesan D, Malcangio M (2009) Rapid isolation and culture of primary microglia from adult mouse spinal cord. J Neurosci Methods 183:223-237. CrossRef Medline

Zhou W, Dantzer R, Budac DP, Walker AK, Mao-Ying QL, Lee AW, Heijnen CJ, Kavelaars A (2015) Peripheral indoleamine 2,3-dioxygenase 1 is required for comorbid depression-like behavior but does not contribute to neuropathic pain in mice. Brain Behav Immun 46:147-153. CrossRef Medline 